Iranian Quarterly Journal of Breast Disease 2018; 11(2):16.

\title{
The Study of Relationship Between Epstein - Barr virus and Breast Cancer in Isfahan Province
}

Salahshournia Z: Department of Biology, Faculty of Science, Lorestan University, Khoramabad, Iran Hejazi H: Department of Biology, Faculty of Science, Lorestan University, Khoramabad, Iran Hadi F: Department of Biology, Faculty of Science, Lorestan University, Khoramabad, Iran Saeedi Z: Department of Biology, Faculty of Science, Lorestan University, Khoramabad, Iran

Corresponding Author: Seyed Hesamaldin Hejazi, hejazi.h@lu.ac.ir

\begin{abstract}
Introduction: Breast cancer is one of the most common malignancies in women. Although the etiology of breast carcinoma is not completely understood, exposure to Epstein-Barr virus (EBV) is suggested as a risk factor for breast cancer. Studies have reported since 1995 that EBV is involved in the development of breast cancer. The aim of this study was to assess the presence of EBV in patients with breast cancer in Isfahan province.
\end{abstract}

Methods: This study was performed using 40 paraffin-embedded tumor tissues and 40 tumorfree breast tissues from women with breast cancer in Isfahan province. After extraction of the DNA using salting-out method and the amplification of housekeeping gene beta- actin, all samples were examined for EBV DNA using PCR (polymerase chain reaction) method. Data were analyzed with chi-square test using SPSS 16software.

Results: EBV was detected by PCR in 20 out of $40(50 \%)$ cases of breast cancer samples and 5 out of $40(12.5 \%)$ control samples. The chi-square statistics for the analysis of EBV infection in tumor and normal samples was 0.000 indicating a significant relationship between breast cancer and EBV infection in Isfahan province.

Conclusion: The presence of EBV gene in a significant subset of women with breast cancer in Isfahan province shows EBVcan be one of the reasons for breast cancer, but more studies are needed to demonstrate the relationship between the virus and breast cancer.

Keywords: Breast Cancer, Epstein- Barr virus, PCR, Isfahan province 


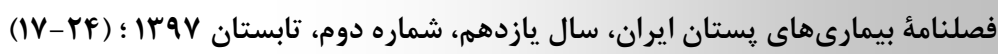

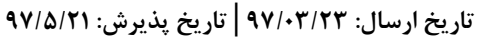

\title{
بررسى ارتباط بين ويروس إشتين- بار و سرطان پِتان در استان اصفهان
}

\author{
زهرا سلحشورنيا: كروه آموزشى زيست شناسى، دانشكده علوم، دانشكاه لرستان، خرم آباد، ايران

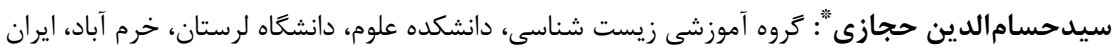

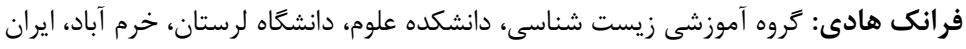 \\ زهرا سعيدى: كروه آموزشى زيست شناسى، دانشكده علوم، دانشخاه لرستان، خرم آباد، ايران
}

مقدمه: سرطان يستان يكى از شايعترين تومورهاى سرطانى در زنان است. علت سرطان پستان به طور كامل شناخته نشده

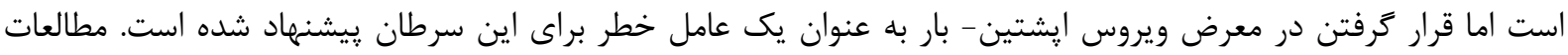

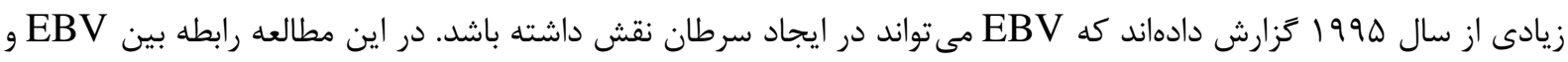

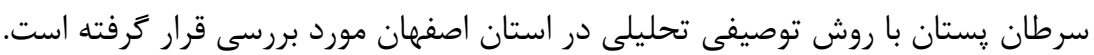

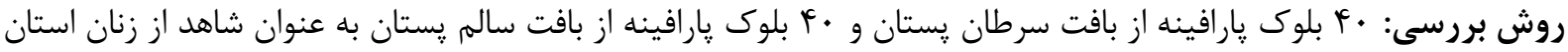

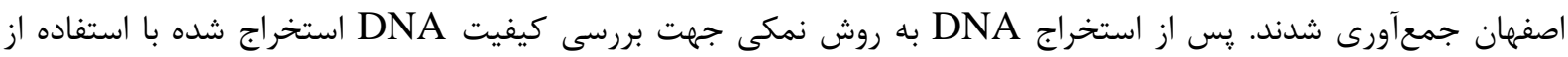

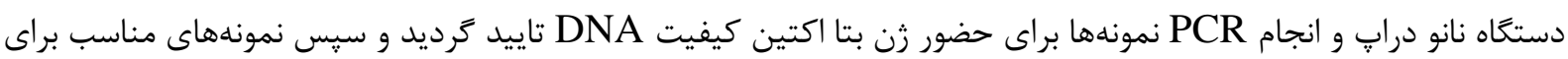

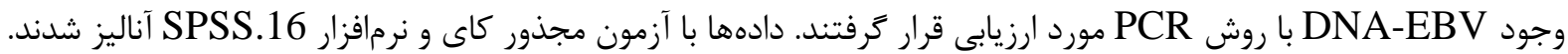

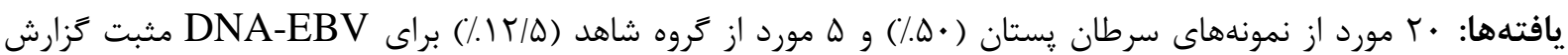

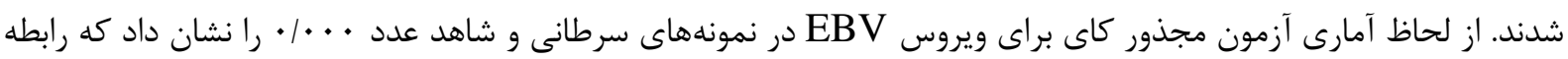

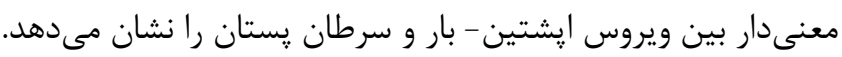

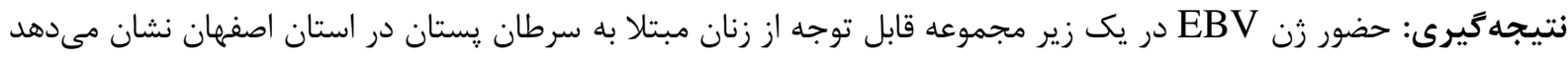

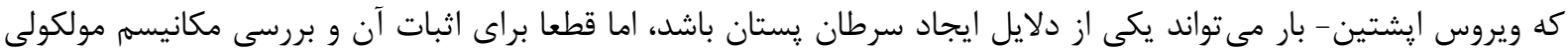
اين ارتباط مطالعات بيشترى لازم است. وازههاى كليدى: سرطان يستان، ويروس ايشتين - بار، واكنش زنجيرهاى يليمراز، استان اصفهان 
عفونتهاى ينهان مىشود (ه). در صورت كنترل ويروس

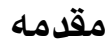
به واسطه ياسخ ايمنى ميزبان، عفونت نهفته ويروس در دران

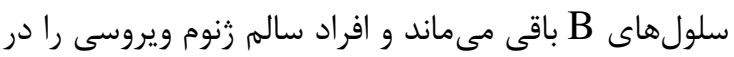
سلولهاى B خود حمل مى كند (س ا ). عفونت نهيفته عمدتا

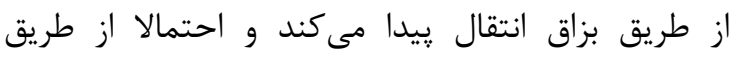

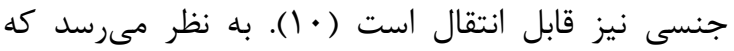

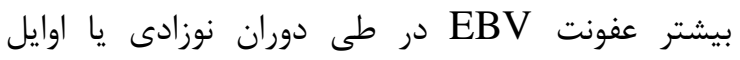
كودكى اتفاق مىافتد (IV). نتايج مطالعات مختلف نشان مىدهد كه مى توان بين سرطان يستان و آلودَى ويروسى آنى

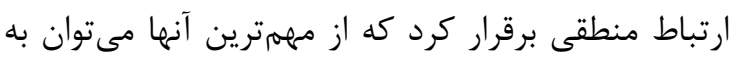

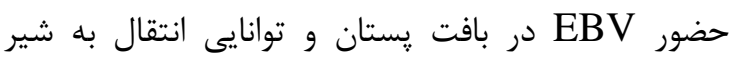

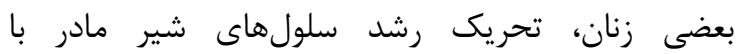

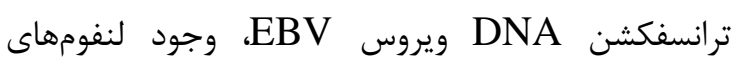
مرتبط با EBV در يستان و همجنين مشاهده

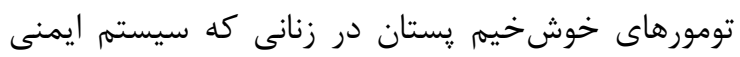
آنها سركوب شده است و نيز در مواردى در شرايط بنائ

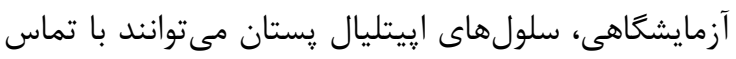

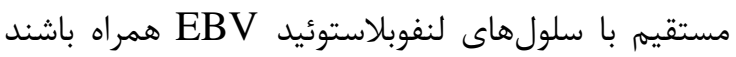
(r)( اين احتمال كه سرطان يستان مجرايى و لوبولار

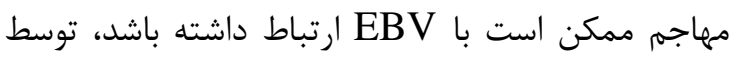
Labreque

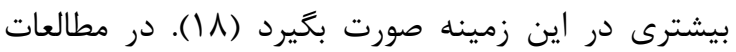

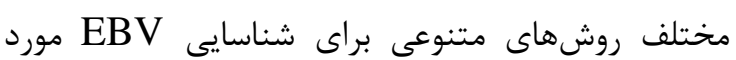

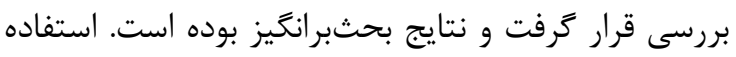

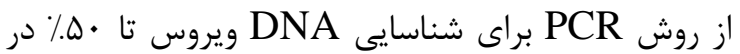

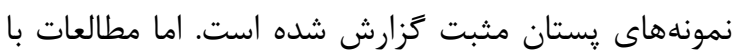

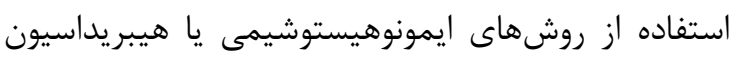

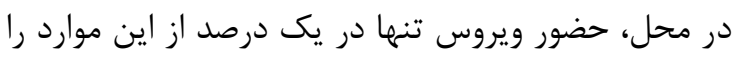

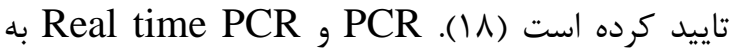
عنوان حساسترين روش براى تشخيص EBV مطرده

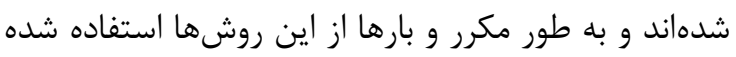

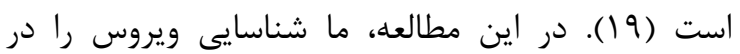

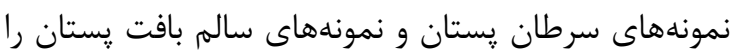

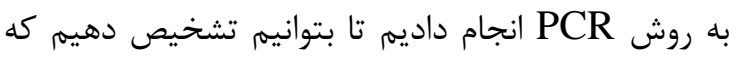

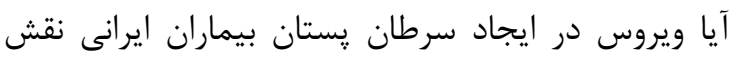

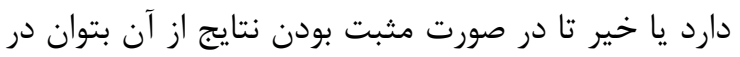

$$
\text { ييشخيرى و درمان نيز استفاده كرد. }
$$

سرطان קستان يك مشكل عمده بهداشت عمومى در سراسر جهان و دومين علت مرى و مير در ايالات متحده

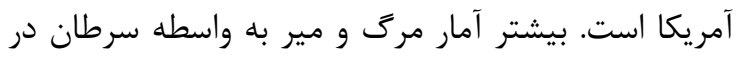
هر دو جنس زنان و مردان مربوط به سرطان ريه است و

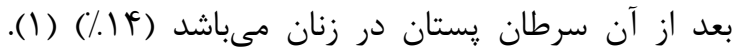

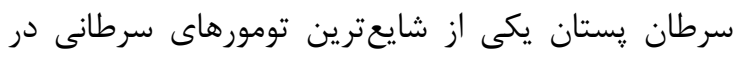

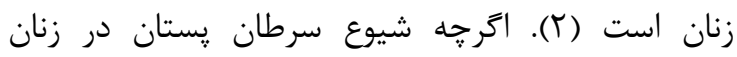

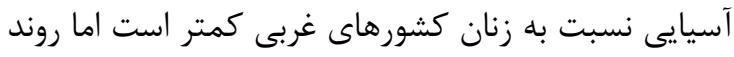

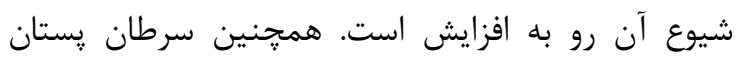

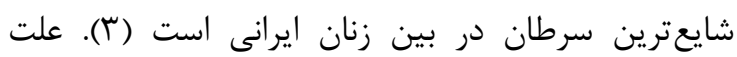

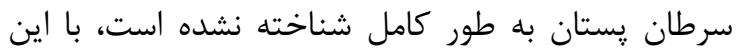

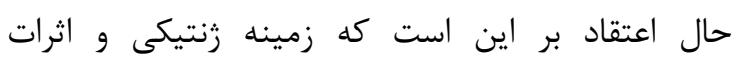

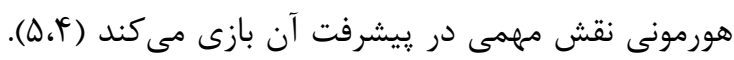

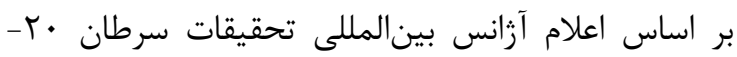

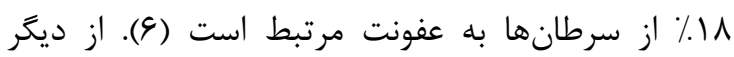

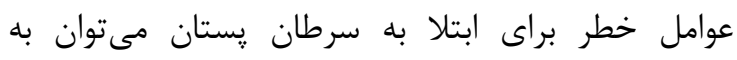

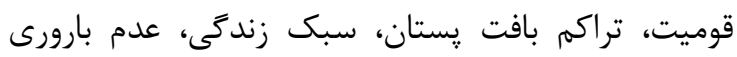

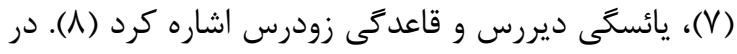

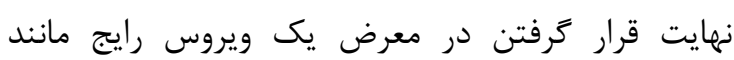

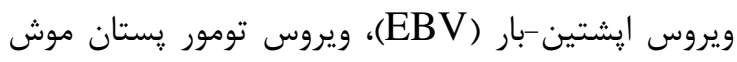

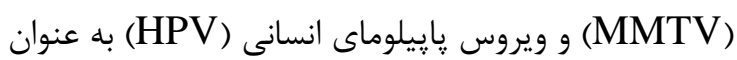

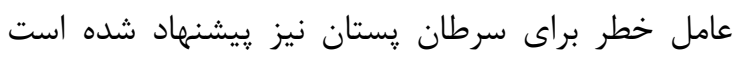

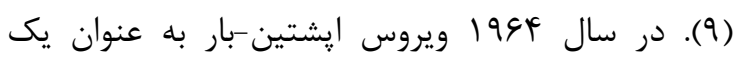

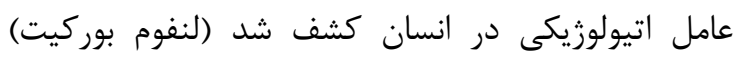

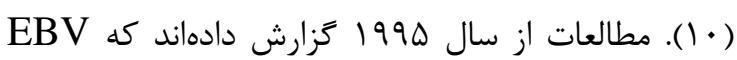

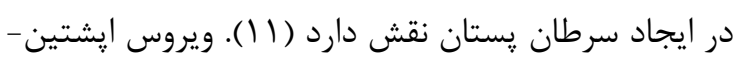

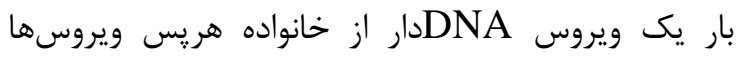

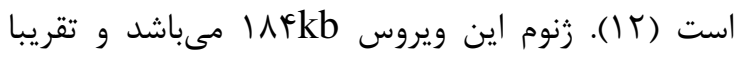

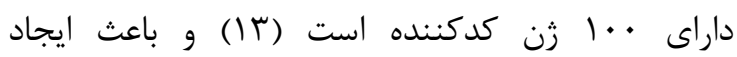

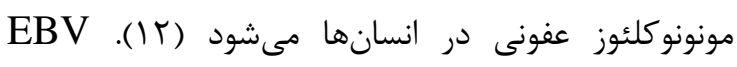

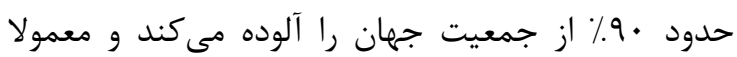
حامل يك عفونت طولانى مدت و بدون علامت است (1) (1).

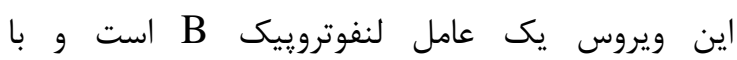

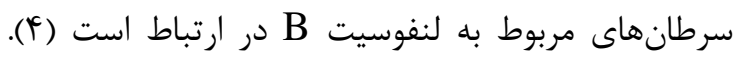
EBV

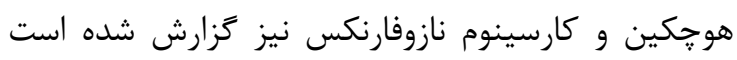

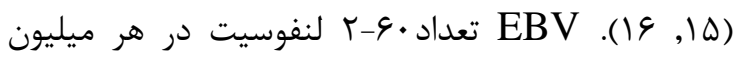

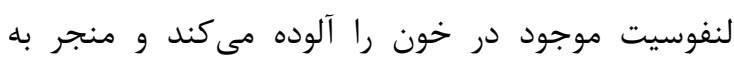


اتاق، در مقدار مناسب آب حل شد (براى حل DNA در

مواد و روشها

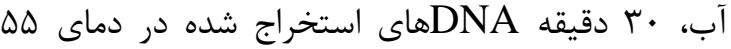

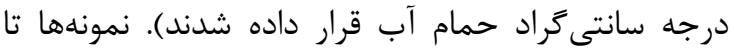

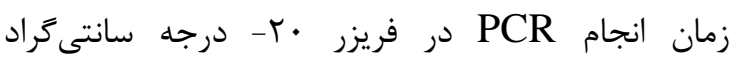

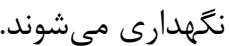

ارزيابى خلوص و كيفيت DNA استخراج شده: غلظت و خلوص DNA استخراج شده با استفاده از

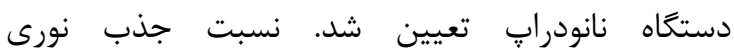

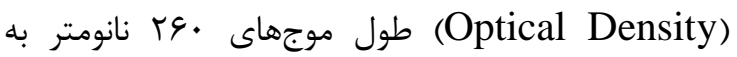

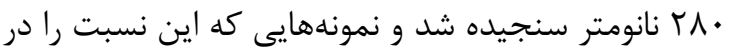

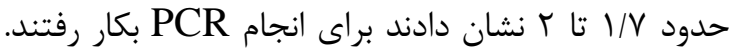

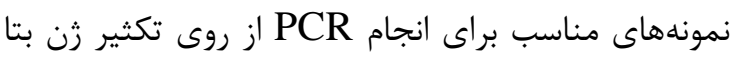
اكتين با آغازگر اختصاصى آن زن تعيين شدند (جدول ()).

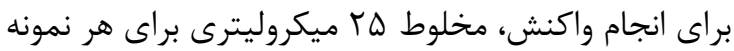

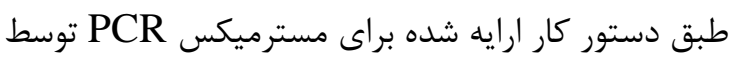

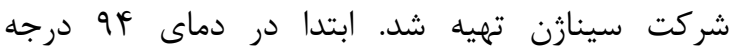

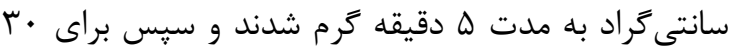

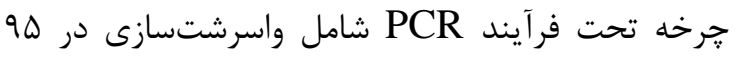

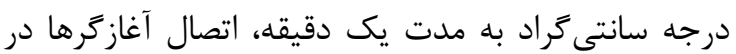
دماى او درجه سانتى

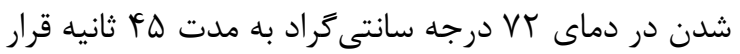

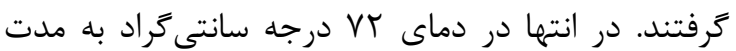

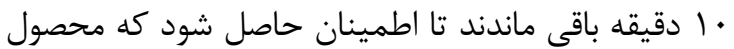

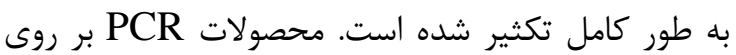

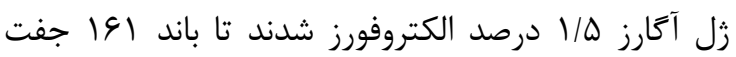
بازى مشاهده شود.

انجام واكنش PCR براى بررسى حضور ويروس ايشتين-بار هر كدام از نمونهها كه براى زن بتا اكتين مثبت بودند،

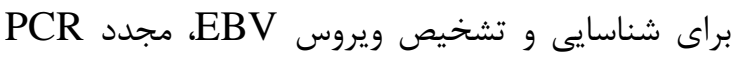
شدند. در اين مرحله جون بايد ويروس احتمالى در

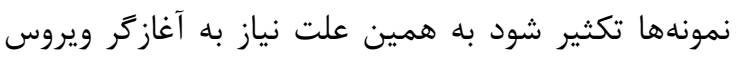

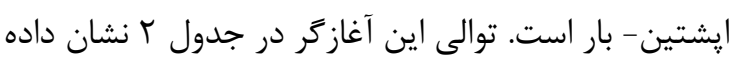

براى PCR نمونهها در يك ميكروتيوب آ/ ميلىليترى،

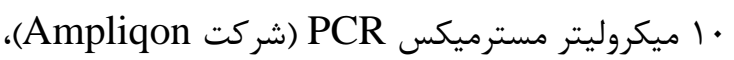

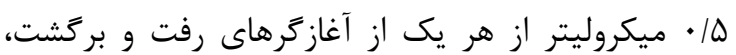

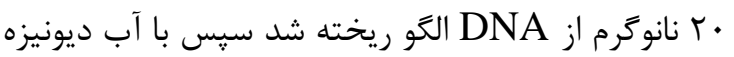
حجم نهايى واكنش به • r ميكروليتر رسانده شد. تهيه نمونه و استخراج DNA: • • نمونه بلوك پيارافينه

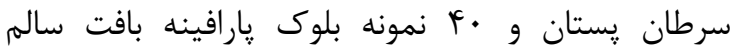

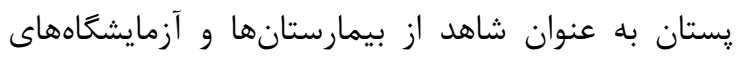
پاتولوزى استان اصفهان جمعآورى شد. بلوكهاى انتخاب

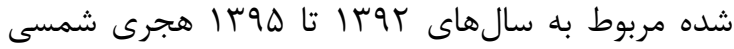

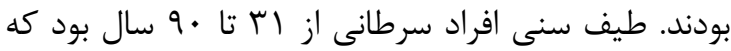

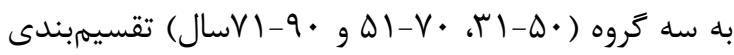
شدند كه بيشترين تعداد افراد سرطانى مربوط به سنين

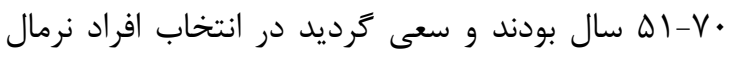
به اين توزيع سنى توجه گردد و نمونههاى كنترل با دقت درد دان

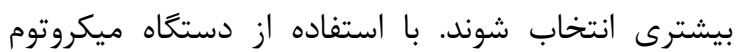

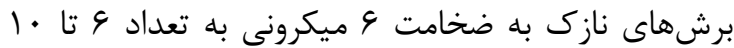

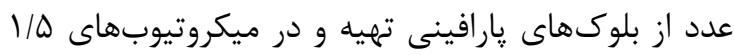

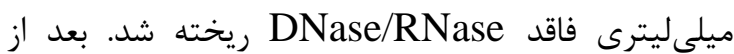
ديارافينه كردن نمونها با كزيلن (MERK/آلمان) و

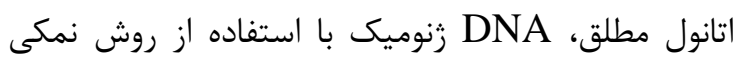

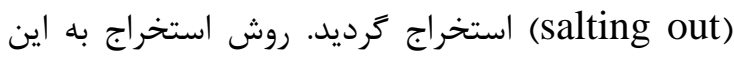
ترتيب بود كه به هر كدام از نمونهها . له ميكروليتر بافر

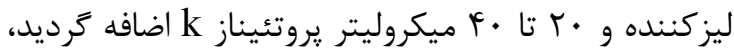

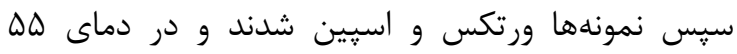
درجه سانتى كراد حمام آب به صورت يكى شبانهروز قرار

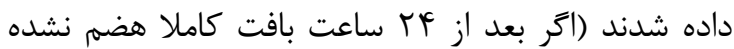

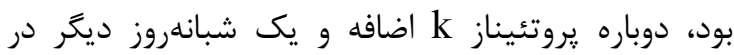

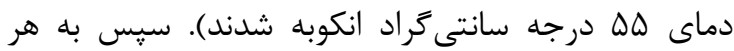

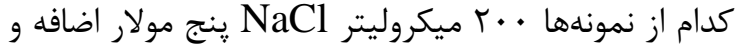

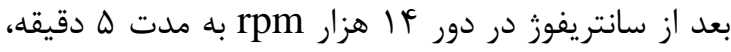

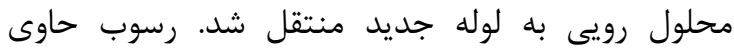
يروتئين و نمك دور ريخته شد. به محلول رويى انتقال

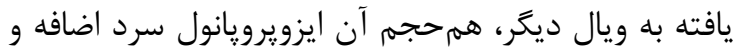
با سروته كردن، كاملا مخلوط شدند. براى افزايش رائ راندمان كار، ميكروتيوبها به مدت يك ساعت در فريزر • ·- درجه

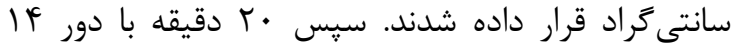
هزار rpm سانتريفوز شده و محلول رويى دور ريخته شد.

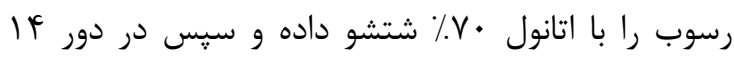
هزار rpm به مدت ه دقيقه سانتريفوز گرديد. اين مرحله دو بار تكرار شد تا DNA به طور كامل شستشو داده شود. در آخر بعد از خشك شدن كامل رسوب در دماى ناى 
جدول ا: توالى آغازگرهاى ثن بتا اكتين و مشخصات آن

\begin{tabular}{|c|c|c|c|c|c|}
\hline آغازگر & 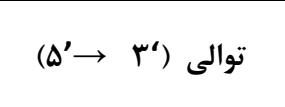 & اندازه & دماى اتصال & درصد GC & $\begin{array}{c}\text { اندازه محصول } \\
\text { (bp) PCR }\end{array}$ \\
\hline رفت (Act F) & $\begin{array}{l}\text { AGACGCAGG } \\
\text { ATGGCATGGG }\end{array}$ & 19 & $G Y / 4 \mid$ & $q \pi / 1 q$ & 191 \\
\hline برَشت (Act R) & $\begin{array}{c}\text { GAGACCTTCAA } \\
\text { CACCCCAGCC }\end{array}$ & rI & GT/qr & $91 / 9$. & 191 \\
\hline
\end{tabular}

جدول r: توالى آغازگر هاى ثن ويروس إشتين - بار

\begin{tabular}{|c|c|c|c|c|c|}
\hline آغازگر & 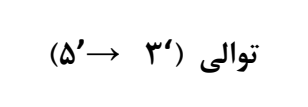 & 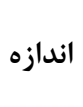 & دماى اتصال & درصد GC & $\begin{array}{c}\text { اندازه محصول } \\
\text { (bp) PCR }\end{array}$ \\
\hline رفت(EBV F) & $\begin{array}{l}\text { TCTTGATAGGGA } \\
\text { TCCGCTAGGATA }\end{array}$ & TF & $\Delta 9 / V V$ & $F \Delta / \Lambda r$ & fqr \\
\hline برخشت(EBV R) & $\begin{array}{l}\text { ACCGTGGTTCTG } \\
\text { GACTATCTGGAT }\end{array}$ & $T F$ & GT/9G & $\Delta \cdot / \cdot$ & fqr \\
\hline
\end{tabular}

آناليز آمارى: براى آناليز آمارى، دادهها بر طبق آزمون

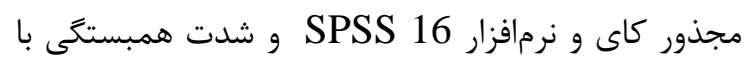
آزمون كرامر مورد بررسى قرار كرفتند.

\section{لـافتهها}

استخراج DNA و مبرسى كيفيت آن: پس از استخراج DNA از بافتهاى سرطانى و غيرسرطانى كيفيت آن مورد بررسى قرار كرفت. نتايج نشان داد تمامى سافى نمونهها جذب نورى و غلظت قابل قبولى با دستخاه نانو

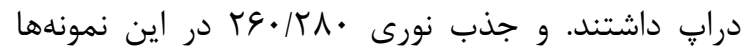

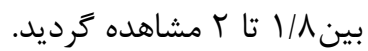
در ادامه با DNA هاى مذكور توسط آغازكرهاى اختصاصى زن خانه دار بتا اكتين واكنش PCR انجام شد.

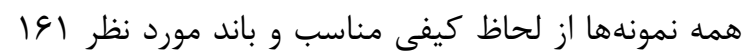
را تكثير نمودند (شكل (1).
برنامه دمايى براى PCR زن EBV شامل مرحله آغاز در دماى fq درجه سانتى

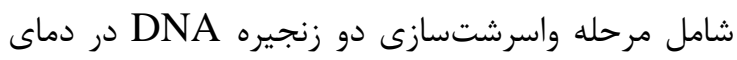

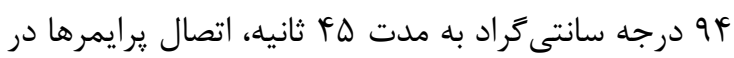
دماى Ff درجه سانتى شدن در دماى Vr درجه سانتى گراد به مدت dأ ثانيه و

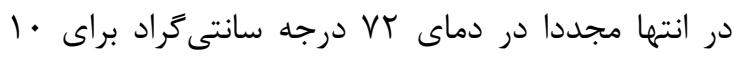
دقيقه باقى ماندند تا اطمينان حاصل شود كه محصول به دمايه PCR طور كامل طويل شده است. جهت تاييد محصولات بر روى زل آكارز ه/ \٪ الكتروفورز شدند تا باند بازى مشاهده شد. در تمامى مراحل براى تشخيص

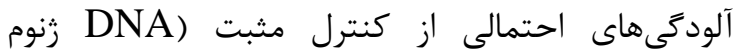
ويروس) و كنترل منفى (آب) استفاده شد.

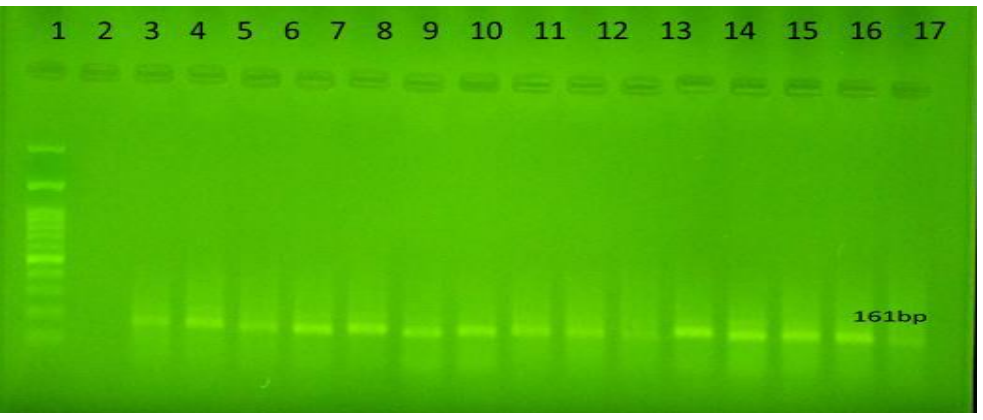

شكل ا: الكَوى الكتروفورز محصول PCR زن بتا اكتين در نمونههاى سرطانى و شاهد. جاهك ا: نشانَر وزن مولكولى 100bp، جاهك

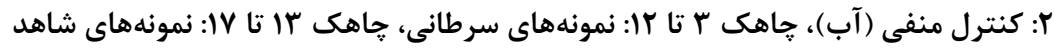


اجتناب نايذير مىنمايد (f (). يكى از عوامل خطرى كه در كنار ساير عوامل براى اين سرطان در نظر گرفته مى شود إنى مىتوان به ويروسهاى القا كننده سرطان اشاره كرد. اينها ويروسهايى هستند كه قابليت تغيير شكل سلول را داشته و در نتيجه منجر به تكثير خارج از كنترل سلولهاى مورد نظر مىشوند. اين تكثير زياد، باعث ايجاد تومور يا سرطان

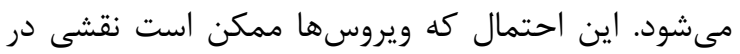

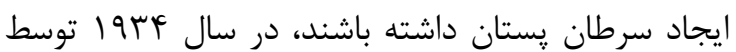
جان بيتنر و همكارانش آغاز شد. آنها مشاهده كردند كه در شير موش يك فاكتور ناشناختهاى وجود دارد كه در

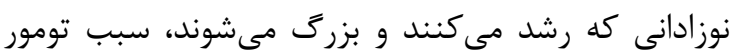

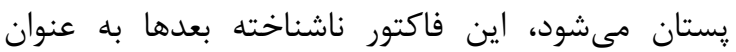

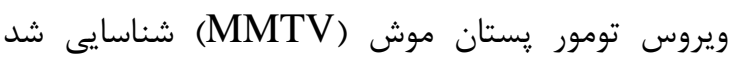

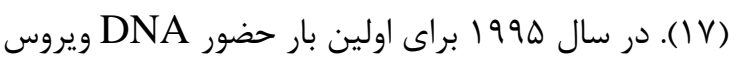
در سرطان يستان توسط Labreque

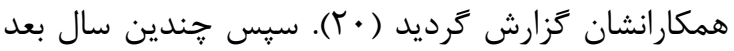

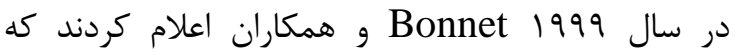
ويروس إشتين-بار مىتواند به عنوان يك كوفاكتور در

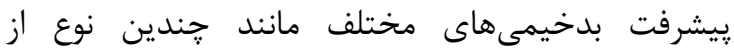

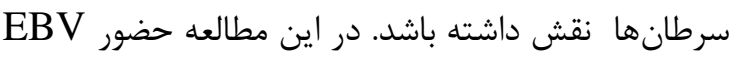

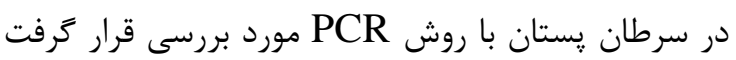

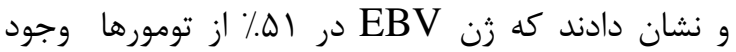

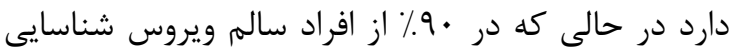

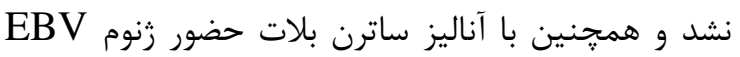

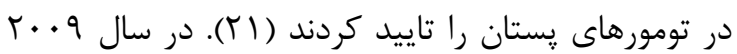

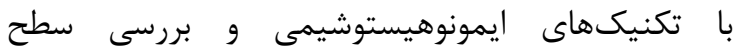
آنتىبادى ها بر عليه آنتى زن هستهاى ويروس إيشتين - بار

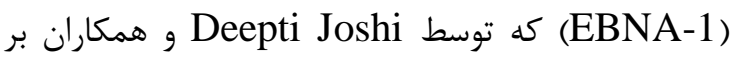
روى زنان روستايى هندى مبتلا به سرطان يستان صورت

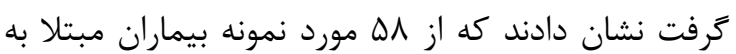

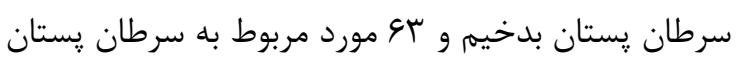

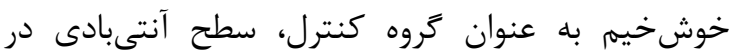
نمونههاى بيمار بدخيم در مقايسه با كروه شاهد خيلى بيشتر بود. و اين بيماران نيز پاسخ ايمونولوزيك شديدترى دئري

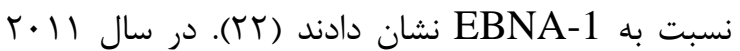
Mazouni

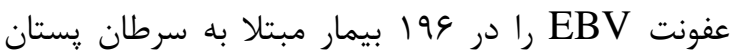

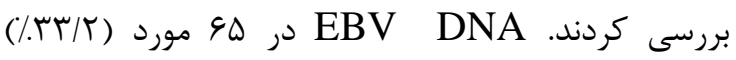
حضور داشت. بر طبق نتايج اين آزمايش بيماران كه حضور
انجام واكنش PCR براى بررسى حضور ويروس

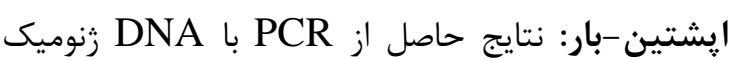
مربوط به نمونه إى سرطانى و شاهد با كمك آغازگرهاى اختصاصى ويروس EBV نشان داد كه از • • نمونه بافت

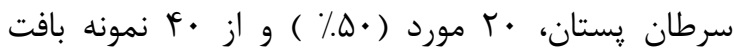

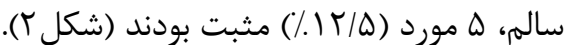

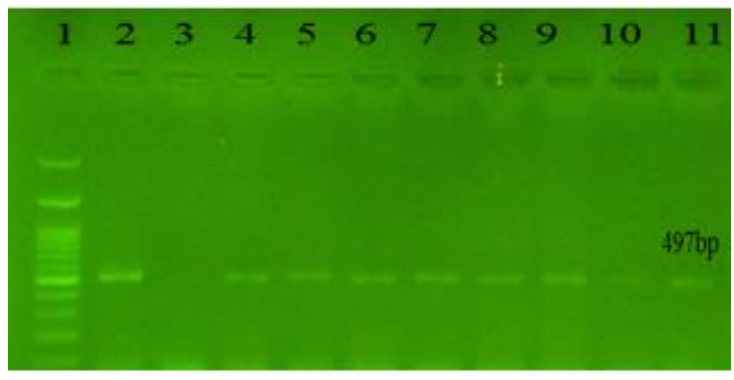

شكل r: نتايج PCR برخى نمونههاى بافت سرطانى با استفاده

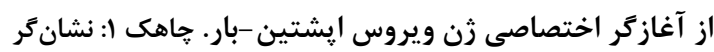

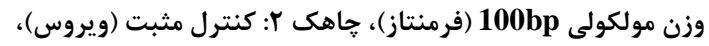

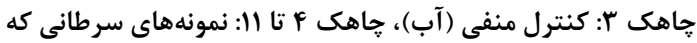

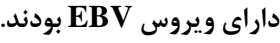

آناليز آمارى: براى آناليز آمارى، دادهها بر طبق آزمون

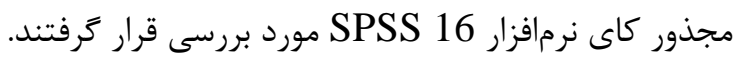
نتايج مجذور كاى با توجه به اينكه سطح معنادارى (sig) كمتر از هـ••• است اختلاف دو گروه معنادار است و

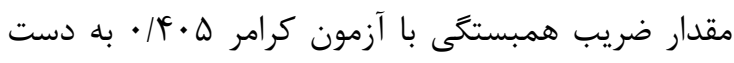

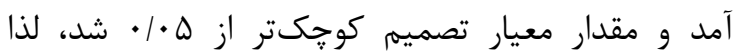

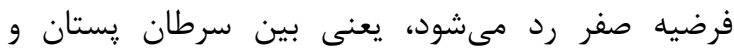
ويروس إشتين - بار رابطه معنى دارى وجود دارد.

\section{بحث}

على غرم يیشرفتهاى علمى اخير، سرطان همجنان دومين

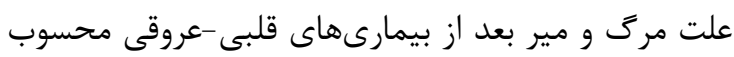

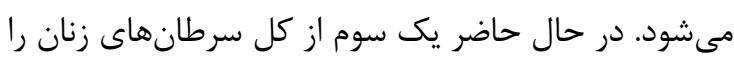
سرطان קستان تشكيل مىدهد. همجنين يس از سرطان

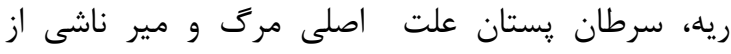

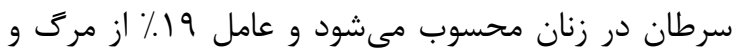
ميرهاى وابسته به سرطان در زنان مىباشد (YN). سرطان يستان يك بيمارى קند عاملى داراى يتانسيل كشندگى

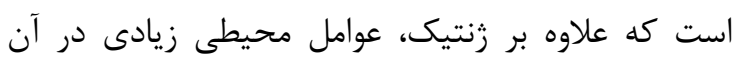
نقش دارند با توجه به اينكه عوامل زنتيكى وريسك زئيك فاكتورهاى رايج تنها درصد كمى از مبتلايان را به خود

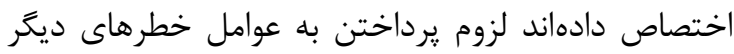


تفاوت در تجزيه و تحليل يروتئينهاى حاصل از EBV يا

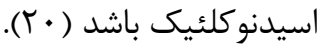

\section{نتيجهكيرى}

در اين مطالعه، نتايج ما حضور زن EBV در يك زير مجموعه قابل توجه از سرطان يستان زنان استان اصفهان را نشان داد. كه در راستاى مطالعاتى است كه ارتباط بين

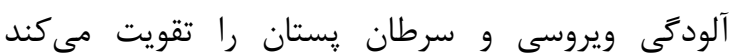
بنابراين ممكن است EBV نقشى در ييشرفت و توسعه

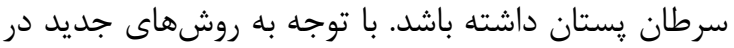
درمان بدخيمىهاى مرتبط با EBV، اميد است كه درصد قابل توجهى از تهاجم سرطان يستان را با داروهاى ضد

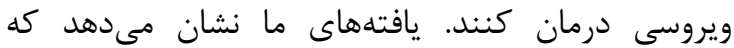
ويروس ايشتين-بار مىتواند يكى از دلايل ايجاد سرطان يستان باشد. بر اساس يزوهشى كه انجام داديم از تعداد

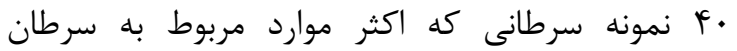

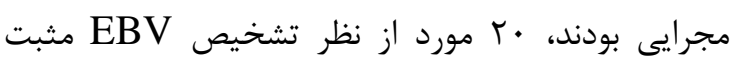
بودند (•ه./) اين در صورتى است كه از •^ نمونه سالم فقط ينج مورد مثبت كزارش شد. اين يافتهها نشاندهنده

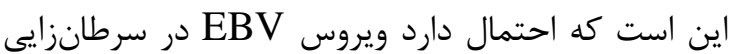

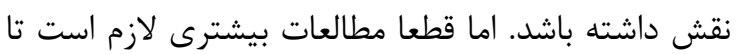

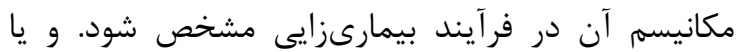

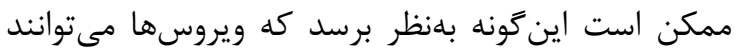

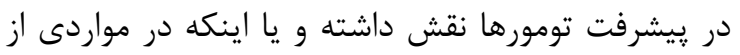
سرطان يستان كه كيرنده استروزن منفى هستند عاملى براى اين تومور باشند و از طرفى افراد با مليتهاى متفاوت

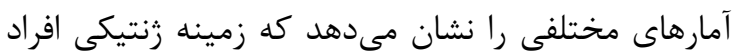

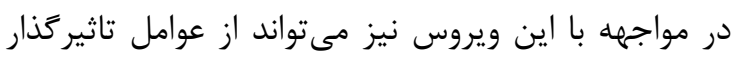
در نظركرفته شود بنايراين بيشنهاد مى ويروس در مراحل مختلف بيمارىزايى و در انواع خاصى از

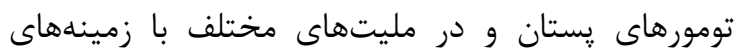
زنتيكى متفاوت بررسىهاى بيشترى صورت كيرد.

\section{References}

1. Siegel RL, Miller KD, Jemal A. Cancer statistics. CA Cancer J Clin 2016; 66(1):730 .
ويروس ايشتين-بار در آنها مثبت بود، نمونه تومورهاى آنها فنوتيب تهاجمىترى داشتند كه در مطالعات قبلى آنس هم به آن اشاره شده بود و نكته جالبتر اينكه بيشتر اين بيماران كيرنده استرورن منفى بودند و بيان بان بالاى فئل فعاليت

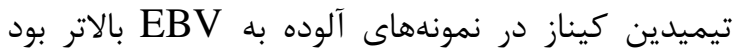
(Tr)

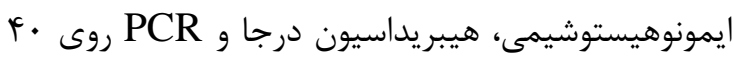

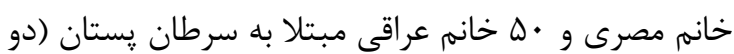
مليت متفاوت) توسط Zerki و همكارانش صورت كرفت نشان دادندكه ويروس EBV در هـ

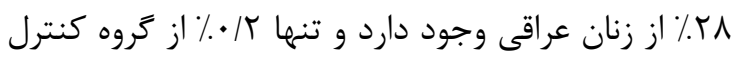
حاوى ويروس EBV بودند. در نتيجه بيان كردند كه ارتباط معنى دارى بين حضور EBV و

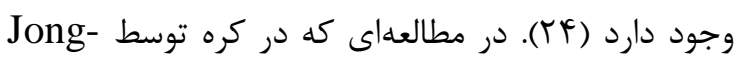
Myon Bae مجموع · r مطالعه موردى- شاهدى انتخاب شد و تعداد

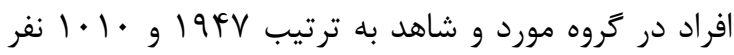
بBV بودند. يافتههاى اين متآناليز نشان داد كه عفودن مى تواند خطر ابتلا به سرطان يستان را افزايش دهد (Yه).

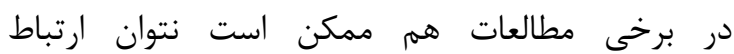
معنى دارى بين سرطان يستان و

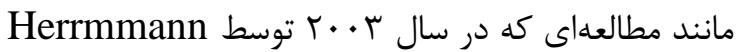
Niedobitek انجام دادند (צا). و يا مطالعهاى كه

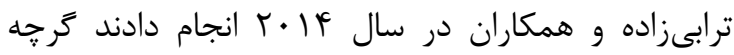
حضور اين ويروس در نمونههاى سرطانى بيشتر بود (TV). همانطور كه اشاره گَرديد در طول دهه كَّشته، ارتباط EBV

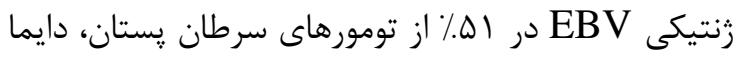

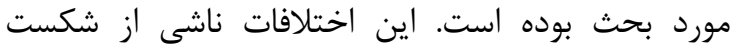

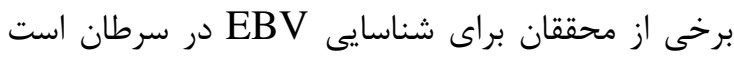

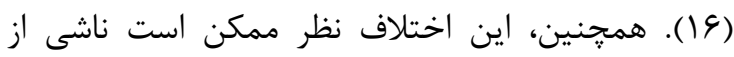

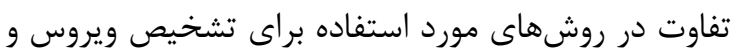

2. Wu Y, Sun W, Feng J. Antiangiogenic therapy in the management of breast cancer. Asia Pac J Clin Oncol 2013; 9(2):110-6. 
3. Otaghvar HA, Hosseini M, Tizmaghz A, Shabestanipour G, Noori H. A review on metastatic breast cancer in Iran. Asian Pac J Trop Biomed 2015; 5(6):429-33.

4. Hippocrate A, Oussaief L, Joab I. Possible role of EBV in breast cancer and other unusually EBV-associated cancers. Cancer Lett 2011; 305(2):144-9.

5. Chu PG, Chang KL, Chen YY, Chen WG, Weiss LM. No significant association of Epstein-Barr virus infection with invasive breast carcinoma. AmJPathol [Internet]. 2001;159:571-8.

6. Alibek K, Kakpenova A, Mussabekova A, Sypabekova M, Karatayeva N. Role of viruses in the development of breast cancer. Infect Agent Cancer 2013; 8(1):32.

7. Key TJ, Verkasalo PK, Banks E. Reviews Epidemiology of breast cancer 1865; 44(0):133-40.

8. Bonnet M, Guinebretiere JJ-M, Kremmer E, Grunewald V, Benhamou E, Contesso $\mathrm{G}$, et al. Detection of Epstein-Barr Virus in Invasive Breast Cancers. JNCI J Natl Cancer Inst 1999; 91(16):1376-81.

9. Wang T, Chang P, Wang L, Yao Q, Guo $\mathrm{W}$, Chen $\mathrm{J}$, et al. The role of human papillomavirus infection in breast cancer. Med Oncol 2012; 29(1):48-55.

10. Joshi D, Buehring GC. Are viruses associated with human breast cancer? Scrutinizing the molecular evidence. Breast Cancer Res Treat. 2012;135(1):115.

11. Marrão G, Habib M, Paiva A, Bicout D, Fallecker C, Franco S, et al. Epstein-Barr virus infection and clinical outcome in breast cancer patients correlate with immune cell TNF- $\alpha / \mathrm{IFN}-\gamma$ response. BMC Cancer 2014; 14(1):665.

12. Ribeiro-Silva A, Ramalho LNZ, Garcia $\mathrm{SB}$, Zucoloto $\mathrm{S}$. Does the correlation between EBNA-1 and p63 expression in breast carcinomas provide a clue to tumorigenesis in Epstein-Barr virus-related breast malignancies? Brazilian J Med Biol Res 2004; 37(1):89-95.

13. Glaser SL, Hsu JL, Gulley ML. EpsteinBarr virus and breast cancer: state of the evidence for viral carcinogenesis. Cancer
Epidemiol Prev Biomarkers 2004; 13(5): 688-97.

14. Fawzy S, Sallam M, Mohammad Awad N. Detection of Epstein-Barr virus in breast carcinoma in Egyptian women. Clin Biochem 2008; 41(7-8):486-92.

15. Arbach $\mathrm{H}$, Viglasky $\mathrm{V}$, Lefeu $\mathrm{F}$, Guinebretière J-M, Ramirez V, Bride N, et al. Epstein-Barr virus (EBV) genome and expression in breast cancer tissue: effect of EBV infection of breast cancer cells on resistance to paclitaxel (Taxol). J Virol 2006; 80(2):845-53.

16. Murray PG. Epstein-Barr virus in breast cancer: artefact or aetiological agent? J Pathol 2006; 209(4):427-9.

17. Lawson JS, Heng B. Viruses and breast cancer. Cancers (Basel) 2010; 2(2):752-72.

18. Herrmann K, Niedobitek G. EpsteinBarr virus-associated carcinomas: facts and fiction. J Pathol 2003; 199(2):140-5.

19. Fadavi P, Rostamian M, Arashkia A, Shafaghi B, Niknam HM. Epstein-barr virus may not be associated with breast cancer in Iranian patients. Oncol Discov 2013; 1(1):3.

20. Labrecque LG, Barnes DM, Fentiman IS, Griffin BE. Epstein-Barr virus in epithelial cell tumors: a breast cancer study. Cancer Res 1995; 55(1):39-45.

21. Bonnet M, Guinebretiere J-M, Kremmer E, Grunewald V, Benhamou E, Contesso $\mathrm{G}$, et al. Detection of Epstein-Barr virus in invasive breast cancers. J Natl Cancer Inst 1999; 91(16):1376-81.

22. Joshi D, Quadri M, Gangane N, Joshi R, Gangane N. Association of Epstein Barr virus infection (EBV) with breast cancer in rural Indian women. PLoS One 2009; 4(12):e8180.

23. Mazouni C, Fina F, Romain S, Ouafik L, Bonnier P, Brandone JM, et al. EpsteinBarr virus as a marker of biological aggressiveness in breast cancer. $\mathrm{Br} \mathrm{J}$ Cancer 2011; 104(2):332.

24. Zekri A-RN, Bahnassy AA, Mohamed WS, El-Kassem FA, El-Khalidi SJ, Hafez $\mathrm{MM}$, et al. Epstein-Barr virus and breast cancer: epidemiological and molecular 
study on Egyptian and Iraqi women. J Egypt Natl Canc Inst 2012; 24(3):123-31.

25. Bae J, Kim EH. Epstein-Barr Virus Infection and Risk of Breast Cancer: An Adaptive Meta-Analysis for Case- Control Studies 2016; 11(3) .

26. Herrmann K, Niedobitek G. EpsteinBarr virus-associated carcinomas: facts and fiction. J Pathol 2003; 199(2):140-5.
27. Torabizadeh Z, Nadji A, Naghshvar F, Nosrati A, Parsa M. Association between Epstein-Barr Virus (EBV) and Breast Cancer. Res Mol Med 2014; 2(4):24-9.

28. Hejazi S.H, Ahangari G, Pornour M, Deezagi A, Evaluation of gene expression changes of serotonin receptors, 5-HT3AR and 5-HT2AR as main stress factors in breast cancer patients Asian Pac J Cancer Prev 2013; 15(10): 4455-8.

29. 